This item was submitted to Loughborough's Research Repository by the author.

Items in Figshare are protected by copyright, with all rights reserved, unless otherwise indicated.

\title{
Print, religion and identity: The cultural significance of Thomas Gage
}

PLEASE CITE THE PUBLISHED VERSION

http://dx.doi.org/10.1080/14788810.2017.1372968

\section{PUBLISHER}

Taylor \& Francis (Routledge)

VERSION

AM (Accepted Manuscript)

\section{PUBLISHER STATEMENT}

This work is made available according to the conditions of the Creative Commons Attribution-NonCommercialNoDerivatives 4.0 International (CC BY-NC-ND 4.0) licence. Full details of this licence are available at: https://creativecommons.org/licenses/by-nc-nd/4.0/

\section{LICENCE}

CC BY-NC-ND 4.0

\section{REPOSITORY RECORD}

Armstrong, Catherine M.. 2019. "Print, Religion and Identity: The Cultural Significance of Thomas Gage". figshare. https://hdl.handle.net/2134/26163. 


\title{
Print, Religion and Identity: The cultural significance of Thomas Gage
}

\author{
Catherine Armstrong*
}

\begin{abstract}
This article revisits the Atlantic significance of Thomas Gage, by placing his experience in the context of the religious turmoil of the seventeenth century and of stories of other converts from Catholicism, showing that his biographers' judgement of him, as uniquely heinous, is unjustified. Five aspects of his life are explored, illustrating the complexities of his experience and the liminality of his identity. His early life as a Catholic, the renouncing of his faith in 1642, his life as an author, a traveller and a propagandist are discussed, concluding that Gage’s hybrid identity was an example of the way that isolated figures in the Anglo-Atlantic world negotiated a safe passage through the religious turmoil of the early Stuart and Civil War eras.
\end{abstract}

Keywords: Thomas Gage; religion; identity; print culture; travel.

Thomas Gage (c.1603-1656) was an unusual travel writer. He wrote with the aim of furthering the Protestant English cause, yet he was born a Catholic and was educated by Jesuits. He wanted to promote the potential of the Atlantic world to an English readership and yet he wrote about New Spain. For most of his period abroad, between 1625 and 1637, he claimed to have pined for England, yet he was conflicted about his identity, calling himself the "English-American", which is the title of the book he wrote recounting his travels. This

\footnotetext{
*E-mail: c.m.armstrong@lboro.ac.uk
} 
was recorded first as manuscript notes (which do not survive) while he was abroad, and then published in 1648 a decade after his return to England. His narrative was the product of a unique eyewitness experience, yet some of his text was copied from other written sources. This was shaped by Gage's use of hindsight to craft his narrative, because of his desire to justify himself to the English authorities, and by the flaws in his memory in the intervening decade between his returning to Europe and the publication of his book. Gage was unpopular and ridiculed during his years in England, yet his book went through four editions in seventeenth-century England and several on the continent.

Thomas Gage's life and writing have been hitherto neglected and yet he was a culturally important actor in the early modern Atlantic world. His treatment by scholars perfectly illustrates that taking a purely national, or hemispheric, approach to history means that certain liminal people and ideas fall through the gaps. It was Gage's ability to selfconsciously physically and metaphorically cross boundaries that marked him as an important exemplar in the study of the Atlantic world. He was a product of the white Atlantic world, but made detailed and, at times, nuanced observations of the Native, or Red, Atlantic. ${ }^{1}$ Much of the historical work on the Atlantic world has referred to the networks of exchange in the Anglo-Atlantic or North Atlantic world - David Armitage’s "cis-Atlantic world". ${ }^{2}$ The concept of the "trans-Atlantic", looking at the region in the light of national contexts, is also relevant for this study, as seen through the work of John Elliott, which crucially highlighted the similarities as well as differences between the English and Spanish early modern Atlantic worlds. ${ }^{3}$ Finally, the "circum-Atlantic", the most challenging of Armitage's categories encouraging us to think trans-nationally, most clearly illuminates the many contexts through which Gage was moving, where at different times, nominally being a part of the Atlantic world of the Jesuits, the Dominicans, the Spanish empire in America and more broadly of people of European descent in relation to those of native, African or mixed heritage that he 
met, allowed him to survive despite his often anomalous, challenging position in relation to the local systems of authority.

The stories of very few historical individuals from the first half of the seventeenth century can contribute to the study of England, continental Europe, and Central America. Gage genuinely moves Atlantically but also, I argue, thinks and behaves Atlantically as well. This paper argues that despite his attempts to fashion himself as an English Protestant, there is evidence for his fluid Atlantic identity throughout his writing. Earlier scholars have mined his travel narrative for evidence of native culture, especially of foodways, while others have chosen to tell his story as that of a renegade Catholic. ${ }^{4}$ I argue that he should be considered from an Atlantic Studies perspective as illustrating the rich potential of the discipline to alert us to boundary transgressing and mutability. Rather than presenting his life as a chronological biography, this article probes five aspects of Gage's identity: Gage the Catholic, the renegade, the author, the traveller and the propagandist. What is most interesting about Gage is that these aspects of his identity were not chronologically distinct but rather overlapped and intersected in complex ways throughout his life as he moved around the Atlantic and as he fashioned his place in this fast-changing religious and political climate.

As well as spatially moving around the Atlantic world, Gage was a truly transnational figure who moved effortlessly between different religiously and nationally focused networks when it was expedient to do so. As well as being an observer of human and non-human ecologies of the Atlantic, of imperial structures and of emerging creole and mestizo identities, Gage contributed an important and relatively understudied text to the flow of knowledge from West to East and, in his final journey as part of Cromwell's Western Design and his death from disease in Jamaica, became part of the story of the lost, unnamed thousands of Europeans, Natives and Africans who met an untimely death in the Atlantic failing in their pursuit of imperial dreams. A tragic end for the author who saw himself as "The English- 
American”, but one which allows us to further interpret the state's use, for its own ends, of liminal figures such as Thomas Gage.

\section{Gage the Catholic}

Gage was born, probably around 1605, to a fairly wealthy recusant family in Sussex. Both his mother and father had previously been imprisoned for harbouring priests and, in return for their lives, they forfeited their family home at Haling, Surrey. ${ }^{5}$ A cousin was executed in 1586 for his part in the Babington plot. The year of Thomas Gage’s birth and the Gunpowder Plot was a notorious period when Catholics and their supposed treacherous nature were at the forefront of people's minds. During the late sixteenth and early seventeenth century heightened public fear of Catholics ebbed and flowed but was constantly present. Rumours of Catholic uprisings affected many localities in England but, in most people’s minds, the fear of Catholicism was connected with international rather than local politics. The rivalry with the great Catholic power, the Spanish, on the Atlantic and world stages further exacerbated the fear of Catholics domestically, especially as the precious metals flowing from the 'New World' was economically and thus politically radically changing the balance of power in Europe. But the Catholic Church itself was the most demonised of the European-based power structures. The Book of Homilies stressed the Pope's interference in the Church of England's autonomous organisation. Catholicism was thought to be a corrupt version of Christianity and the Pope thought to be the antichrist. ${ }^{6}$ To be Catholic was to be politically suspect and, increasingly, an English national identity was a Protestant one - attitudes carried throughout the Atlantic World and reinforced by narrative collections such as those by Richard Hakluyt and Samuel Purchas.

Historians have assumed that although there was considerable regional variation, Catholics were treated less harshly by penal law under James I and Charles I than they had 
been under Elizabeth. ${ }^{7}$ This suggests that Gage's recusant family were in a better situation during the early decades of the seventeenth century as the siege mentality of Elizabeth's reign had been lifted. This is an overly simplistic interpretation. James and Charles may have had a personal tendency towards leniency towards Catholics (especially so after the marriage of Charles to French Catholic Henrietta Maria) and only treated recusants harshly to please their advisors and Parliament. They were concerned about Catholics who posed a political threat to their rule but were equally worried by Puritans. It was the increasingly radical Protestant Parliament, and especially John Pym, who put pressure on the monarch to reintroduce and reinforce recusancy laws. This happened at the start of the reigns of both monarchs, in 1603 and again in 1625. Although few Catholics were put to death, many were imprisoned for failure to pay the fines. Towards the end of Charles's reign, lay Catholics were hounded and blackmailed by pursuivants and informers, while being a Catholic priest or member of an order was a criminal offence usually punished by death. The gaol delivery roll recording the charging of Thomas's brother, George, in the early 1650s, indicated the state's view of the crime as an attack on the political order and on the public peace, saying that George "beyond the seas was made and ordained a priest by the authority described and pretended from the sea of Rome...the laws and statutes of England little weighing nor the punishment in the same...[Gage] did traitorously and as a false traitor to this Commonwealth of England and did stay, was and remayned against the forme of the statute in that case made and provided. And against the publique peace."8

The publishing by former Catholics of pamphlets that reinforced the Protestant view of Catholics as traitors against England, such as John Gee’s Foot out of the Snare (1612) and Richard Sheldon's Motives of Richard Sheldon Priest (1624), further aroused hatred of Catholics. ${ }^{9}$ Jesuits were seen by Protestants as particularly evil because they represented both the international conspiracy and the enemy within. The rooting out of Catholicism was not 
seen as radical or as mindless persecution, but as a rational and sensible way to defend the true religion. ${ }^{10}$ Beleaguered Catholics were heartened by the martyrdom of the Jesuit, Edmund Campion, in 1581. Catholic families such as Gage’s were inspired by the accounts of the deaths of heroic martyrs, which were circulated in printed and manuscript form and also by the veneration of relics. The martyrs also became models for the expectations of Catholic priests coming to England to preach. $^{11}$ Much Catholic activity focused on connections and networks with European Catholics, as in Gage's family when he and his brothers were sent abroad around 1612 to be educated by Jesuits, first at St. Omer (situated between Calais and Lille in north-west France), and later in Valladolid, Spain. At the end of his education in Spain, as a young man away from his family network, Gage was deciding which doctrine suited him, and also defining his identity as an Englishman and as a Catholic. Dionisia Tejera believes that Gage was "hispanised” during his schooling, but politically the Spanish empire still considered him a foreigner, denying him freedom of movement in the Atlantic colonies. ${ }^{12}$ But Gage certainly became familiar with the Spanish language, culture and religious controversies being taught that Protestants (and indeed pagans such as Native Americans) were akin to devil worshippers and that the true Catholic Church was under siege from these forces.

At the end of his schooling, according to his own account, Gage rejected the Society of Jesus, much to the chagrin of his father, and joined the Dominicans. He gave no explanation for this change of direction. The theme of conflict between the Jesuits and the Dominicans recurs throughout Gage’s literature and his life, and indeed in the Atlantic World as the Spanish authorities viewed the multi-national Jesuit order with increasing suspicion by and they were eventually expelled from New Spain in 1767, at which time many of their missions in what is now Mexico and the south-western United States were taken over by the Dominican and Franciscan orders. Gage’s choice to become a Dominican friar, made in 
Spain in the early 1620s, affected him almost as much as his rejection twenty years later of Catholicism in favour of Protestantism. Gage’s rejection of the Jesuits was part of his search for identity and clarity, but as he himself recorded, this resulted in further estrangement from his family. The nineteenth-century local historian recording events in Gage’s home of Haling, Surrey, suggested that Thomas's decision to go to America was triggered by this rejection by his family. ${ }^{13}$ According to his own writing, Gage genuinely felt that he would be unwelcome if he returned home, but it is also probable that he did not want to be supervised and cloistered within an English recusant family. Gage was a pragmatist and did not relish the thankless task of going to the English mission field. Thus, in 1625, Gage left Europe on a Dominican missionary expedition, surreptitiously with the connivance of fellow friars because he knew that his status as a foreigner entering Spanish imperial territory made his position vulnerable. Although destined for the Philippines, Gage designed to remain in Mexico when the ship from Cadiz docked there and spent the next twelve years in Central America. The merchant fleet in which he travelled confirms the well-developed Atlantic trade between Cadiz and Puerto Rico, Santo Domingo, Jamaica, Margarita, Havana, Cartagena, Campeche, Honduras and Vera Cruz - all destinations of ships in which the friars sailed, carrying along with their human cargo commodities such as wine, figs, raisins, olives, woollens, linen, iron and quicksilver for the silver mining process. ${ }^{14}$

Some authors suggested that the Thomas Gage interviewed and detained by the Privy Council in 1617 was the same Thomas, but there is no evidence that Gage returned from Spain at this time and, in any case, he would have been a young boy of around twelve. The Acts of the Privy Council detail this Gage being detained at the houses of several merchants in London during $1617 .{ }^{15}$ Norman Newton hypothesised that during this period Thomas was indoctrinated as an English spy, and hence his entire Catholic career is a sham. Certainly some of the information included in The English-American indicates that Gage observed 
aspects of life useful to English invaders, such as whether towns or ports were fortified or not. But it was standard practice for English travellers to make notes on military defences of the cities they visited, and so this does not indicate that Gage was acting as a spy. His behaviour and rhetoric used in 1642, after his recantation of Catholicism in London, justified his actions and defended his Protestantism; they did not reflect the attitude of mind of a spy working secretly for the English for many years. We also cannot assume that Gage was acting for England throughout his time in New Spain. ${ }^{16}$ For historians to consider him either loyal to Spain or England misunderstands his complex significance as a boundary crossing, liminal, circum-Atlantic figure. Although Gage had growing doubts about his faith while in America, he was still considering his options within Catholic organisations on his return to Europe in 1637, although the precise timing of his decision to convert to Protestantism is unclear. At Cartagena, while waiting to secure passage back to Spain, Gage met with Edward Layfield and had many meaningful conversations about religion, as Gage put it "both at Carthagena and in the way in the ship I had great discourse concerning points of Religion, and by him came to know some things professed in England, which my conscience (whilst I lived in America) much inclined unto.”17

In 1637 after returning to Europe from New Spain, Gage had to consider his future. In his book The English-American, Gage suggested that he had been having serious doubts about Catholicism while abroad. On his arrival in San Lucar, Spain, on the way home from the Americas, he yearned to symbolically "cast off his fryers weeds that outward sheepskin which covers many a wolfish greedy and covetous heart." 18 While there he changed into a suit of clothes made by an English tailor "and being now cloathed after a new fashion and ready to lead a new life; being now changed from an American into the fashion of an Englishman”, he left for England, shedding his Catholic and American (that is, Spanish American) identities as easily has he had done his clothes. ${ }^{19}$ But in England he did not 
immediately declare his desire to convert, probably because his alienation peaked as he was unable to speak English "I was much troubled within myself for want of my mother tongue which made mee fearfull I should not bee acknowledge to bee an English man born.” He sought out his relatives, and was distressed to find that he was excluded from any inheritance. He could not settle into life with his recusant relatives, who barely knew him and probably assumed him long since dead. He recorded that Lady Penelope Gage "laughed at mee telling mee that I spake like an Indian or Welch man and not like an Englishman.”20

However, for the first three years after returning, some of his behaviour indicated that he wanted to carve a life for himself in Europe within the Catholic fold. In 1639 he was travelling again, unsettled in England and wanting to seek an alternative life. He journeyed to Rome, hardly the actions of someone about to apostacize. In The English-American Gage claimed that he wanted to observe how the Protestant and Catholic faiths operated in Europe and concluded that these observations confirmed his desire to become a Protestant. Norman Newton is sceptical about this statement, believing instead that Gage was seeking preferment from the church and when he was disappointed, he then decided to change sides. ${ }^{21}$ During his time abroad Gage visited his brother, Henry, who was serving with the English army in Ghent. According to Anstruther, at this time Thomas was offered a chance to enter the priesthood in Orleans, which he declined. On his return to England later in 1639, a Dominican report said of Gage that he had not acted against the Fathers, but that he remained much dissatisfied. $^{22}$

It was Gage's decision to return to England and to provide evidence for the Cromwellian state against his former co-religionists that attracted the focus of his earlier biographers and they unanimously excoriated Gage for his, as they saw it, false, cynical conversion and the subsequent betrayal of his friends and family. His testimony led to the execution of Peter Wright, the Jesuit who had been chaplain to Thomas's brother, Henry 
Gage, while on campaign in Europe. Authors who recorded the history of Catholic martyrs, such as Henry Foley for the Jesuits and Godfrey Anstruther for the Dominicans, naturally saw Gage as a heinous figure. ${ }^{23}$ Their accounts of his behaviour originated from two Catholic martyrologies, Ambrose Corby’s account of Thomas Holland, Certamen Triplex, published in Antwerp in 1645, and Edward Leedes' work on Peter Wright, Petri Writi Sacerdotis Anglie Society. Jesu. Mors, published in Antwerp in 1651. Leedes was probably present at the trial he recounted, although Corby passed on stories he had heard elsewhere. Leedes mentioned Gage by name and his damning description of him, “infamis apostate, ac verbi iam Praeco inter Sectarios, Londinium accersebatur," was echoed by later biographers Foley in particular often referred to Gage as ‘the unhappy apostate Thomas Gage’. ${ }^{24}$ Leedes’ account of Gage’s ignominy included him breaking a promise to his brother George not to testify against Peter Wright and outlined Leedes' assumption that an interview with Wright had pricked Thomas’s conscience and his evidence against him was given in revenge. Gage also allegedly aroused the disgust of the court by begging for protection from those who sought to have him killed. Leedes also reported hearing discussion among members of the Protestant crowd at the court, some of whom had heard Gage's recantation sermon in 1642. He claimed that they said that "the man appeared to them to be of a wanton disposition and from that time they disliked him, although he was their own preacher.” ${ }^{25}$ The picture painted by such accounts is indeed negative but the motivations of Leedes, and later Foley, must be acknowledged. Martyrologies, including Protestant examples such as Foxe’s Book of Martyrs, emphasised the value of being spiritually steadfast, unchanging and fixed in the face of challenges and physical pain. Therefore, regardless of Gage's testimony against the martyrs, at that time anyone who changed religion was seen as weak, malicious and cowardly.

Gage’s modern biographers have been hardly less biased. In his version of The English-American, published in 1958, J. Eric S. Thompson removed the passages that he 
judged would be offensive to Roman Catholics and referred to Gage as "not a pleasant [character]”. ${ }^{26}$ A decade later, Norman Newton also revealed a prejudicial view of Gage, calling him an unpleasant person.” ${ }^{27}$ While more recent historians have acknowledged Gage's contribution to the knowledge about New Spain, the stain on his reputation originating from the initial pro-Catholic propaganda by Corby and Leedes, has remained unchallenged.

\section{Gage the renegade}

Gage was not the only English Catholic to convert to Protestantism in this period and his story must be considered alongside other conversions. The meaning of conversion narratives in print and the public declarations that they recorded was twofold, both "personal and public,” that is, they reflected the individual's inner experience but also showed that they had been admitted to the Protestant church by agreement of its members. ${ }^{28}$ As part of conversion, the convert had to show repentance by publicly confessing their sins. Gage did this in his recantation sermon, published in 1642 as The Tyranny of Satan. Alongside this sermon, his 1648 narrative of his years living in Central America, The English-American, was also part of the confessional process, exposing to public view the errors of his Catholic life. In this book, Gage placed his conversion into an Atlantic context, claiming that discussions with English Protestants at Cartagena enlightened him to the true nature of Protestant faith. ${ }^{29}$ In the conversion sermon, delivered at St. Paul's six days after the King raised the royal standard at Nottingham, Gage compared himself to Saul, who persecuted the church but then experienced a dramatic conversion. He confessed that he had "sucked my first milk of the whore of Babylon...worshipped creatures and saints instead of my creator...been disloyall and treacherous to my king and country.” He explained that through God's providence he now had a hatred of Catholics, but that he had paid for this with loss of his family and his income. 
In his sermon he also listed the doctrinal errors that he had fallen into, and these were typical of attacks on Catholicism in conversion narratives, such as the worshipping of graven images and the false belief in the true presence. In a story that also appeared in his The EnglishAmerican, he claimed that his doubts about the true presence started in Portobello when he was officiating at mass during which a mouse stole the consecrated wafer. ${ }^{30}$ His dilemma over whether the nibbled wafer was really the body of Christ caused him to doubt Catholic doctrine. In another typical conversion narrative trope, Gage described how he resolved to test his Catholic faith once more. Having lost his belief in transubstantiation, he prayed before the image of Our Lady of Loreto, deducing that a "true" image would reveal his sinful soul. This discovery did not happen and at that point Gage narrated that he decided to visit a Protestant church. ${ }^{31}$ In The English-American, Gage described in vivid detail the lively and very wealthy port of Portobello, the residents' constant fear of disease - Gage called the town an "open grave" - and the fluctuating commodity prices when the fleet arrived and flooded the town with people. He was able to escape from Portobello and sail for Cartagena, despite having no money, because he was still willing to pray and provide Catholic sermons in exchange for his passage. Thus Gage admitted that despite his religious doubts in the period just before he left the Americas, he would pragmatically adopt a Spanish Catholic identity for his own benefit. ${ }^{32}$

Gage probably read many of the conversion narratives that were popular in England, but he also knew other apostates personally. He was a contemporary at St. Omer of James Wadsworth, author of The English Spanish Pilgrim. Although they were published nearly twenty years apart, the similarity in the titles of the books written by Wadsworth and Gage encouraged readers to perceive connections between the two. As well as being a school friend, Wadsworth was, for ten months, imprisoned in France as a spy on the testimony of Gage's brother, George, and also, like Thomas, he gave evidence at the trial of Father Peter 
Wright in 1651. Like Gage’s The English-American, Wadsworth’s book published in 1629 was a travel account and a conversion narrative and also a polemical attack on the Jesuits. It described his early life as the son of recent converts to Catholicism. On the journey from St. Omer to Spain Wadsworth was kidnapped by Moorish pirates. His vivid and entertaining account included stories of sexual abuse and drug taking before his rescue by a French merchant. In the same way that Gage's descriptions of the white Atlantic and its encounter with other Atlantics proved popular with readers, Wadsworth's exotic tale of the racial “other” titillated an English audience. On his return to Spain after his period of captivity, Wadsworth believed himself vulnerable to physical attacks by the Jesuits. He later got his revenge by publicly 'outing' Englishmen who lived in Spain who were furthering the Catholic cause. ${ }^{33}$ Wadsworth was restless and on examining Catholic doctrines, found them unconvincing, and so decided to return to England to become a Protestant. It was on his journey back that he was intercepted by George Gage, Thomas's brother, who accused him of being a spy and had him tortured and imprisoned.

Conversion narratives contributed to the international political debate about the threat of Spanish Catholicism. Recorded in Richard Hakluyt's Principall Navigations, Miles Philips's oral testimony exposed national differences similar to those in Gage's account. Philips, in New Spain from 1568 to 1582, pretended to be a Spanish Catholic in order to survive. While Philips had not actually become a Catholic, his narrative took the form of a confessional conversion narrative as he apologised to an English readership for pretending such a thing to save his life. However, like Gage's work, Philips's account showed that in many ways he was ambivalent towards the Catholic Church. He was familiar with Catholic practice and imagery and his report of the phenomenon of the Virgin of Guadeloupe avoided the usual Protestant preaching about the sinfulness of images and of worshipping the Virgin. As Barbara Fuchs explains, the early modern literary trope of apologising for subversive 
behaviour was not only part of the spiritual tradition, but also reflected the picaresque tradition. $^{34}$

So, Gage’s conversion cannot be taken in isolation; he was influenced by others in the way that he presented his spiritual transformation. It is no coincidence that travel and conversion often appeared together in the narratives. Gage's experiences as a convert, in the England of the early 1640s, might explain his sympathy for the Native Americans expressed in The English-American. Gage, like the Natives, was rejected by his former peers who did not convert, and yet was never properly accepted by members of his new religious family. Gage acknowledged that "converts are hardly believed by the common sort of people." He depicted his decision to marry as a way of proving to the world that his conversion was true. ${ }^{35}$ Gage resorted to informing and spying, not, as his biographers assumed, because he was a corrupt individual, but in an attempt to prove his support for the Protestant English state.

Unlike lay Catholics who lived mostly unmolested in England as long as they attended church or paid fines, Gage, as a Dominican friar, would never have been allowed to live quietly in England following his return in 1637. Recantation followed by a life as a Protestant or as a Church Papist was not possible either. Once he had revealed his intention to recant his Catholicism, the state decided that his position in the Catholic network would be useful to them and required him to work for them. Even when shown leniency by Justices of the Peace influential Catholics were hounded by pursuivants and informers who made money collecting fines and blackmailing their targets. Working alone or in gangs, pursuivants were unpopular figures, living in poverty and isolation. From 1627 onwards, James Wadsworth worked as a pursuivant. In December 1637, on his arrival in England from New Spain, Gage was pestered by the pursuivant John Gray. However, Gray was warned against pursuing Gage because of the intervention of influential friends of George Gage. ${ }^{36}$ This experience made 
Gage realise that he could never live in England as a closet Catholic. He might have lived as a Catholic on the continent, but he had had enough of the factionalism and he was ready to put his wandering behind him and settle in England, despite being unfamiliar with the language and isolated from his family. ${ }^{37}$

Almost immediately on his return to England, Gage made the authorities aware that he wished to recant his Catholicism. Gage’s personal crisis occurred at a moment of crisis for Catholics in England. Strafford had been executed, Archbishop Laud was in the Tower and the Irish rebellion caused the trustworthiness of every English Catholic to be further doubted. Biographer Eric Thompson believes that Gage had no choice but to recant. ${ }^{38}$ But according to Gage’s own words, he was motivated to give evidence against his former friends by being summoned by warrant but also "I weighted the service of my country and the state whose bread I eat and whose protection I enjoy.”39

In 1642-43 Gage’s testimony began to send former friends such as Thomas Holland, another school friend from St. Omer, to the gallows. George Gage was so ashamed by his younger brother's behaviour that he wrote privately to Thomas Holland while the latter was in prison awaiting execution, begging forgiveness from him on behalf of "my graceless brother Thomas.” Henry Foley recorded that Holland's words on the gallows included the hope that his former friend Thomas Gage might be brought back into the Catholic fold. ${ }^{40}$ In 1643, in return for his testimony, Gage was rewarded with the living at Acrise, Kent. The authorities now had Gage where they wanted him, close enough to the capital to be called to testify at short notice and to be monitored to ensure that he was not going "off message."41 Five years later, he was given the more important posting to St. Leonard's in Deal.

After spending several years proving himself as a minister and preparing his magnum opus, The English-American, for publication, in the early 1650s, Gage's activities again resulted in his involvement in a high profile court case, the trial of Father Thomas Middleton 
(his one-time superior as the head of the English Dominicans) and of Peter Wright. While his testimony was crucial in the execution of Wright, Gage saved Thomas Middleton, testifying that he had never personally seen him preside over a Eucharist, so there was not enough evidence to convict him. Could this be further evidence of Gage's loyalty to the Dominican order and hatred of the Jesuits? Although Anstruther believes that Gage paid little heed to doctrinal issues, Gage's accounts of his early experiences at school and then later in New Spain can also be interpreted as those of a strict, committed Dominican, recording his horror at the corruption found within Catholicism, rather than as post-conversion Protestant propaganda. ${ }^{42}$ His difficulties with faith reflect the struggle that many post-Reformation Englishmen had, to find a religion that would satisfy both their intellect and their heart. ${ }^{43}$

He was also aware that rumours had been spread in Kent that he himself had to answer charges. The Calendar of State Papers Domestic confirms Gage’s account, recording his summons to London in November 1649 and listing a request that he be kept in safe custody so that he might present his evidence to the Council. ${ }^{44}$ Gage also garnered sympathy from readers by painting himself as the victim of a Catholic conspiracy, which would have appealed to anti-Catholic readers and depicted him as a hero who, despite threats from vengeful enemies, gave evidence as requested. It is unclear whether Gage genuinely believed there was a conspiracy against him or whether it was a rhetorical device to get support from his readers. Even if his life was not in danger, he was the target of virulent hatred from English Catholics. Gage concluded "if violent death or mischief shall befall me here in town or in my return to Kent...this is my declaration to take notice that through spite and malice, hatred and envious contrivances of bloodthirsty enemies I have been butchered." 45

According to biographers, his most heinous testimony was against his brother George who died in prison awaiting trial, but with the information provided by his brother ready to convict him. However, George Gage had been a person of interest to the state since as early 
as 1628 . While he was in prison in $1650-51$, he was temporarily released and allowed to leave the country to secure the freedom of Richard Beare and John Bushell, English merchants imprisoned in Portugal. The mission must have been a success for Beare later offered himself and Bushell to the Council of State to be exchanged for George Gage's freedom. ${ }^{46}$ That Gage was willing to testify against the brother who, only fourteen years earlier, had used his networks to protect Thomas from pursuivants, reveals a serious fracture. Gage spent much of his life resorting to print to convince himself and others that he had done

the right thing by sending three men to their deaths. ${ }^{47}$ It suggests that he was testifying against others to protect himself either from the threat posed by Catholics or from the threat posed by the Puritan authorities who could take away Gage’s privileges and security as easily as they had given them. It is little wonder that, given the opportunity to pursue his fortunes Atlantically once again, in the mid-1650s, he eagerly took that opportunity, and it was because of his authority as an eyewitness to the realities of life in New Spain that he was given a second chance to cross the Ocean.

\section{Gage the author}

Gage's magnum opus The English-American was written between 1644 and 1646 while he was living with his new wife as incumbent at St. Martin's parish, Acrise, Kent. Gage probably kept a rough manuscript journal while he was in Central America and these notes may have helped him to write his book. He also used passages from other authors, some read during his time in New Spain, others on his return to England. In shaping his book, The English-American, Gage was greatly influenced by his two patrons, one through his place in society and the other through direct friendship. As Andrew Fitzmaurice and David Armitage have argued, English political culture had more impact on Elizabethan and Stuart travel writing about the Americas than has hitherto been acknowledged, even among writers such as 
Gage who had not been educated in the humanist tradition in England. ${ }^{48}$ Gage’s first patron, Thomas Fairfax, who was commander in chief of the New Model Army from its creation in 1645 until 1650, played a major role in the Second Civil War, when he took part in Pride’s Purge, removing all those from Parliament who opposed the New Model Army. He was perhaps the archetypal Parliamentary warrior. ${ }^{49}$ In dedicating the book to him, Gage was indicating that he felt his book was of martial significance to the English nation, that soldiers willing to pick up arms against the Spanish would achieve victory. Thomas Chaloner, the second patron, influenced Gage’s choice of Fairfax. There is no evidence that Gage ever met Fairfax, but he had regular contact with Chaloner through his work as an informant against English Catholics. Chaloner is widely credited with having a major role in shaping the foreign policy of the Commonwealth, and offered his support of Gage's book as part of a wider political strategy. Having offered Gage his patronage, the following year he signed Charles I's death warrant. He endorsed Gage’s proposed Protestant crusade to free the Native Americans from the Spanish yoke, but he was also concerned with overseas markets and saw the Dutch as rivals to English supremacy. Upsetting Cromwell because he was unable to secure Dutch support for an attack on the Spanish holdings in America, Chaloner withdrew from public life and took no part in the Western Design of $1655 .{ }^{50}$ Chaloner encouraged Gage to write and publish his book and contributed a laudatory poem to the work. This poem, referred to by A.P. Newton as 'patriotic and prophetic' placed Gage in a long tradition of travellers who claimed that they did not use the writings of others to create their narratives but rather relied on their eyewitness experience. ${ }^{51}$ The patronage of Chaloner framed Gage's book as a piece of nationalist Protestant propaganda, showing as David Armitage has argued, that the first British Empire was firmly imagined as "Protestant, commercial, maritime and free."52 
The shape taken by The English-American was also determined by English readers’ desire for material on the Black Legend. Popular since the mid-sixteenth century when Gage’s fellow Dominican, Bartolomé de las Casas, published his account of the horrors perpetrated against the Native Americans by the conquistadors, Black Legend material was an intrinsic part of the development of an English Protestant national identity during the reign of Elizabeth I and beyond. The first English version of Las Casas's work was published in 1583 (following the Spanish version in 1552, and the Dutch and French editions of 1578). As well as justifying colonisation and challenging the Spanish in the New World, this material also provided English readers with an ethnographic understanding of Native Americans and a geographical understanding of America. It also made money for printers and booksellers as the sensational, titillating stories attracted a wide readership, in the format of large edited collections of travel narratives for the richer book buyer, and smaller pamphlet literature for the poorer buyer. As Nicholas Canny has shown, all travel literature of this period concerning the Atlantic region was underpinned by the sense of competition, for economic resources, for souls and for the Atlantic space itself, between Protestant and Catholic writers. ${ }^{53}$ Gage's work fits into this trajectory and was popular because it was written by an Englishman, who, even though he was a renegade educated abroad, was seen as more trustworthy than the Spanish authors previously relied upon, who were read in translation. Prior to Gage’s book, the only Englishmen to report on life in New Spain had been illiterate sailors such as Miles Philips. Many of the stories Gage told reiterated the stereotypical view held by the English that the Spaniards were inherently greedy, immoral, cruel taskmasters. He described Governor Valdivia who was "so covetous of the Gold of that country", that he mistreated the native slaves who worked in his mines: he did "whip, beat and yea kill some of them because they brought him not enough.”54 On a larger scale, Gage also described systematic massacres by the Spanish to rid entire regions of the native population, traumatising the few survivors, 
leaving them inconsolable. He wrote of the sixty thousand natives "slayed" on the island of Jamaica, meaning that the "women here as well as on the continent did kill the children before they gave them life, that the issue of their bodies might not serve such a cruell nation.”55

When studying the response of readers to early modern texts, the historian is stymied by the lack of available data. No sales figures emerge from publishers; few sales or auction catalogues, diaries or commonplace books survive. The only evidence for the popularity of Gage's book is that new editions came out: four in fifty years. German, Dutch and French translations were published, showing that the book had a wide appeal in the Protestant nations. However, the publication of these editions was not simply a sales tool. They served as propaganda too; every edition of the book emerged at a time when it was fashionable to challenge Spain. Cromwell himself ordered the publication of the second English edition in 1655, thinking that the work would inspire and justify his Western Design. Very few changes were made to the edition, despite Gage claiming that he had improved his English language skills. The timing of this and subsequent editions maps on to three of Abigail Swingen's administrative turning points influencing seventeenth-century empire-building, and in England's relationship with Spain in the Atlantic world, with the first being the debate over the West Indian colonies under Cromwell. The next two English editions of Gage's book were published posthumously, in 1677 and 1699 under very different political circumstances, again at crucial points of political evolution: the periods immediately following the Restoration and the Glorious Revolution, in which monopoly and international competition, and the limited nature of monarchy, caused publishers to once again revisit The EnglishAmerican. ${ }^{56}$ The Restoration of the monarchy in 1660 meant that the intemperate language of the earlier versions, tailored to appeal to Puritans, was expunged to suit the new mood. The book was no longer dedicated to Thomas Fairfax, but instead simply to The Reader. The 
regicide Chaloner's poem was also dropped in the Restoration editions. The continental versions were released to coincide with the peak of anti-Spanish feeling, particularly the French translation of 1677 sponsored by Jean-Baptiste Colbert, the French finance minister under Louis XIV. ${ }^{57}$ This 1677 translation spawned the subsequent German and Dutch editions. The continental editions were much better illustrated than the English ones. The English editions of 1648 and 1655 had no illustrations and the later two editions of the seventeenth century contained one map of the Caribbean and Central America. However, the continental versions had some detailed but unrealistic woodcuts illustrating Gage's time in Mexico and Guatemala. For example, the 1695 edition published in French by Paul Marret in Amsterdam, depicted Gage’s arrival on the Mexican shore in Dominican friar's habit, while the first German edition, from Leipzig in 1693, published by Johann Herbordt Kloss, depicted

him seated at a table, ledger open, receiving donations from the native population. ${ }^{58}$ Examining the book history of Gage's work reveals that his message and motivation was personal one but were manipulated by patrons and book trade personnel for their own ends.

\section{Gage the traveller}

By examining the text of The English-American we can interpret the self-fashioning of Thomas Gage as an expert Atlantic traveller and observer of the region. This book was Gage's account of his own adventure in New Spain. From 1625 to 1637 he travelled around Mexico, Panama, Guatemala and Honduras before returning to Europe. Gage worked first in Chiapas among the Tzeltal Mayas, before moving on to Guatemala to avoid being sent to the Philippines. From 1627 to 29 he stayed at the Dominican Friary in Guatemala City, now called Antigua, where he ministered to the Cakchiquel Indians. In 1629 he journeyed through dense rainforest to the Chol Mayas of the Petan district before returning to the missions of Mixico and Pinola near Guatemala City. His last posting was in Amatitlan, a remote region 
devoid of Spanish speakers. In 1637 he decided to leave his missionary life and faced a challenging journey through Panama to Portobello and from there to Seville. ${ }^{59}$

Gage’s The English-American tells as much about his self-perception than about the realities of life in Central America. The title of the book shows how conflicted Gage was about his own identity and leads the reader to doubt his assertions that he arrived in England as a Protestant Englishman. In his epistle dedicatory to Sir Thomas Fairfax, he asserted his dual reason for writing, to narrate his conversion and to convey information useful to his countrymen. He depicted England and Protestantism as his "home", writing about "my returning home, not onely to my country but to the true knowledge and free profession of the Gospel's purity." ${ }^{60}$ But the title The English-American complicates this certainty. He might have chosen a title reflecting his assuredness, perhaps describing his book, in the popular style of the time, as “a true account of an English man's travels in New Spain.” But instead he chose the title The English-American. That this choice of title was his is reinforced in the text when Gage acknowledged that his story allowed readers "to observe an English man become American, travailing many thousands miles there.”61 This choice of title is rendered stranger because, in the seventeenth-century meaning of the word, calling someone "an American” did not bring to mind a white Englishman settled in America but rather either of two enemies: a man of Spanish descent who lived in the New World, or a Native American. Through his choice of title, Gage situated himself in his readers' minds as an "other”, saying “I am not like you; I have been changed by my journey”, further complicating his liminal identity as an English renegade Catholic.

Other Catholics who had converted to Protestantism often used the same strategy and attracted readers by giving titles to their books that distanced the authors from their readership, thus turning themselves into the exotic “other.” The closest example to Gage’s book is James Wadsworth's The English Spanish Pilgrim. However, Gage, unlike 
Wadsworth, genuinely saw his identity as flexible. Despite his professed desire to return to England to solve his religious dilemmas, Gage referred to Guatemala as his "second patria" (his second homeland). ${ }^{62}$ This is a significant choice of word, given the tensions in New Spain between criollos and peninsulares, as the criollos (with whom Gage identified more strongly than with the newly arrived Spaniards) began the process by which, over the next century, they defined themselves as different because the New World was their patria. The choice of word also shows the emotional and pseudo-familial ties that Gage felt to the region and its people where he had spent his happiest times. Gage's The English-American, recalling memories of his time in New Spain, altered his attempts to fix his English Protestant identity.

In recent years Gage’s book has gained most notice from historians examining the Columbian exchange. Emerging from Alfred Crosby's seminal work, this argues that the exchange of commodities including foodstuffs had a lasting impact on both white and native cultures in the Atlantic world. ${ }^{63}$ Because of the scarcity of evidence describing the culture of New Spain, Gage's text is a valuable source for scholars studying the food and drink of the region. Also his observations of the spread of disease in the region have been praised by early scholars of tropical medicine, such as B. R. Laurence, who argued that Gage was "much maligned" and was “intelligent and observant."64 Gage is most frequently mentioned in connection with the history of chocolate. In his detailed account of the consumption and cultural meaning of chocolate during this period, he recorded that "I used it twelve years constantly.”65 Gage’s own obsession with food led Edward Valentine Campos to refer to him as "an ethnographic food critic.” 66 Gage’s interest in chocolate reveals a conflict about his identity, because this part of his account does not correspond with his attempt to fashion himself as a strict English Protestant. Contemporary Galenic medical theory questioned the suitability of such drinks for the European body and, as Rebecca Earle has shown, food and drink consumption practices were thought to explain the differences observed between 
different racial bodies. Many colonial settlers feared that if they ate the same food the natives did the nature of their bodies might transform from European to native. ${ }^{67}$ Chocolate had a complex meaning that varied according to the race and class of the consumer. On his first encounter with the drink, Gage referred to it as "the Indian drink called chocolate." (my italics), just as in 1662, Henry Stubbe called it “The Indian Nectar”, in his book, the first in English about chocolate. ${ }^{68}$ Ironically given Gage’s later involvement in the Western Design, it was not until the capture of Jamaica that cacao became a key part of the English imperial trade and then it featured prominently in promotional narratives about the region including that by Stubbe who spent several years in Jamaica. ${ }^{69}$ Prior to that, for the English, chocolate represented something dangerous, mutable, exotic and typically Native American. Gage gave a detailed recipe for the drink because, unlike other Englishmen, he did not see chocolate as a threat to European identity and suggested that it might prevent the abuse of alcohol among the English. ${ }^{70}$

Gage's examination of the lives of Natives, criollos and newly arrived peninsularborn Spaniards provided an in-depth account of the ethnographic complexities of New Spain, and allowed Gage to try to position himself as a good Protestant Englishman. His biographers have portrayed him as being sympathetic to the plight of the Natives while harshly critical of the Spaniards' behaviour, both to perpetuate the Black Legend myth, but also to distance himself from the corrupt representatives of the Catholic Church, and indeed he confirmed the Black Legend, describing how millions of Natives in Guatemala and Hispaniola died through Spanish cruelty. ${ }^{71}$ As with other Protestant travel narratives of the period, Gage's account of his ocean crossing was framed in providential tones, to show how the Protestant God was judging his sinful Catholic companions. In an implicit criticism of the idolatry of the Catholic Church, he described how his friend Antonio Melendez's "gilt and painted idol" fell 
overboard during a storm. ${ }^{72}$ Gage chastised the Catholic Church for its efforts to "delude the ignorant people...[with] fat, proud prelates and abbots.",73

Laws to protect the Natives were constantly flouted and many of the Indians lived very poorly, not only, according to Gage, because of the tyranny of the Spanish friars and because of the Natives' recourse to "chicha" - a corrupting alcoholic drink. ${ }^{74}$ Gage was also discomforted because he observed similarities between the religions of the Natives and the Spaniards, depicting both as idolaters "for do they not deck and adorn their idol saints as the heathens did Vitzilopuchtli and Tezcatlpuca?"75 He also said that Indians liked Catholicism because the image worship appealed to them "they look upon them as much like unto their forefathers idols”. The use of iconography associating a saint with a particular animal further reinforced this. ${ }^{76}$ Protestants since Luther had drawn parallels between Catholicism and magic and Gage’s post-conversion views influenced his interpretation of his time in New Spain. $^{77}$

Some Natives had been converted to Christianity and Gage described a "tawny Indian fryer" who offered gifts and bribes to the Pope and cardinals such as "a box of pearles, some rubies or diamonds, a chest of chochinill or sugar with some boxes of curious chocolate.”78 But he explained that many of the Natives had been left in a state of semi-paganism, as he told stories of witchcraft, animal cults and idol worship showing that Natives had not completely replaced their own religious beliefs. He told how he refused to allow a woman suspected of witchcraft to take communion and also described others who were "in secret great idolaters.” ${ }^{79}$ The recounting of these stories by Gage had a mixed reception in England. He argued that he did not want "to bring an aspertion on all that nation [the Natives] which I doe very much affect and would willingly spend the best drops of blood in my veines to doe them good and save their soules but to cause rather pity and commiseration." ${ }^{80}$ He showed that the Natives were still living in a state of sin and needed the Protestant English to rescue 
them. But the survival of native culture challenged the Black Legend, which claimed that the Spanish had cruelly subdued the Natives, and also struck fear into readers who were worried about the wild nature of the Indians and were doubtful that the English should settle in such a region.

Gage was honest about his own willingness to engage in moneymaking practices, taking advantage of the Natives’ desire for spiritual guidance. In Mixco the Natives suffered plagues of locusts, disease, storms and an earthquake, all of which brought them flocking to his church. When he travelled to Vera Paz, he earned money for his passage back to England and he was especially scathing about his own behaviour in Nicoya suggesting that Lent was "the friar's chiefest harvest." ${ }^{81}$ Gage also identified the conflict between criollos and peninsulares in Oaxaca. His assessment showed that he distinguished between the corrupt and the kind hearted. He described how he became part of the conflict in Chiapa as the criollos feared him and wanted him gone, while the peninsulares wanted him to stay longer to improve their balance of power. ${ }^{82}$ Because he disliked newcomers from Spain, a criollo in Chimaltenango decided that Gage must be a spy for the Spanish against the criollos. Elsewhere Gage was accused of spying by Friar Alonso Hidalgo because Gage came from England and Hidalgo thought England "a country of hereticks" and "hee feared rather that I might come as a spie to view the riches of that their country and betray them hereafter to England.” Gage responded by making a joke about the ignorance and greed of the English, saying that he would guide any English invaders to Friar Hidalgo's home where they would steal his false teeth to see what precious metal they were made of! ${ }^{83}$

In a laudatory poem at the start of The English-American, Richard Chaloner asserted that Gage was an eyewitness to everything that he had described. Readers had no need to turn to illustrious authors such as Hakluyt, Purchas, Ramusio, Acosta, Herrera or even authors of Greece and Troy such as Thucydides; Gage’s account superseded those because of his 
eyewitness presence in New Spain and because his account described the interior and not only the coastline. ${ }^{84}$ But Chaloner's praises were inaccurate. Works by earlier Spanish authors influenced Gage's chapters ten to twelve, describing the region round Mexico City and also Cortés's invasion. The concept of plagiarism is anachronistic for the early modern period. Many authors borrowed large sections of text from elsewhere without attributing them; the idea of authors "owning" the intellectual rights to their text only came later during the eighteenth century. Frederic Rosengarten Jr. argues that Gage deliberately gave a British readership what they wanted, further Black Legend stories, and that he was directly influenced by the work of Las Casas. ${ }^{85}$ However assumptions that Gage was solely influenced by the writings of Las Casas are incorrect. He used Spanish and English versions of Gonzalo Fernandez de Oviedo y Valdez's Historia general y natural de las Indias Occidentales, first published in Seville in 1535 and partly rendered into English in 1577 by Richard Eden, although a full English version was not published until the nineteenth century. Oviedo was a Spanish eyewitness whose work was criticised by Las Casas as being overly sympathetic towards the Spanish cause. Gage did not share Oviedo's view of Native Americans, that some were destined to remain savages and attempting their conversion was fruitless. ${ }^{86}$ Oviedo also wrote a chivalric romance while living in Santo Domingo, showing the melding of interest in traditional Spanish literary forms and in natural history, for Spanish readers Oviedo’s accounts were akin to romances.

Gage also used excerpts from Francisco Lopez de Gomara’s Hispania Victrix, first published in Saragossa in 1552. Although he was Cortés’s chaplain in the last few years of his life, Gomara's was not a first hand account. His work was criticised by those such as Bernal Diaz, who accompanied Cortés, and Diaz wrote his own tract partly to refute Gomara's version. It is unsurprising that Gage used Gomara's text as his source of information about the Cortés expedition because the Spanish crown repudiated it soon after 
publication in 1553 and Philip II ordered all copies be gathered in and a fine issued to those who attempted to reprint it. The Spanish monarch reacted in that way because, immediately after publication, authors outside Spain used excerpts of Gomara's book in an attempt to perpetrate the Black Legend. Gomara did argue that conquest of the Natives and their territory must precede conversion. ${ }^{87}$ Philip's act of censorship ensured that for a Spanish audience Gomara's work was restricted but it was available in translation across Europe, suggesting that Gage accessed this work in English when he had returned from the New World. The nineteenth-century poet Robert Southey accused Gage of plagiarising a 1576 English translation of Gomara's work by Thomas Nicholas. A.P. Newton, Gage’s twentiethcentury editor, denied this saying that “Gage’s translation was made independently from Spanish authorities” but he offered no supporting evidence. ${ }^{88}$ Gage used the Latin text of Jesuit eyewitness Jose de Acosta's account of the natural and human history of the region, published in Salamanca in 1588. Scholars such as Walter D’Mignolo have said that Acosta's work helped to 'invent' the New World for a European audience. ${ }^{89}$ Acosta's frequent use of the eyewitness trope may have influenced Gage to adopt the same. Gage also used extracts from Antonio de Herrera y Tordesillas’s Historia General de los Hechos de los Castellanos en las Islas y Tierra Firme del Mar Océano which was itself partly copied from Oviedo and Las Casas but with the more explicit descriptions of Spanish cruelty removed. Like Tordesillas, Gage wrote a history of people’s deeds; his focus was not geography or natural history. Gage did not acknowledge his sources, but he referred to works that both supported and criticised Spain's behaviour in the empire. Some of these works were available in English translation, although, because of his education, Gage was more comfortable using Spanish and Latin. ${ }^{90}$

Some aspects of Gage's style reveal the influence of his continental education. On the surface much of his work is explicitly anti-Spanish and anti-Catholic, but Gage’s formative 
years imbued in the Spanish way of life were significant. His style incorporated favoured literary tropes from Spanish literature of the Golden Age: the picaresque (in which a lower class roguish hero lives by his wits), the capa y espada or "cloak and dagger" (involving a swashbuckling hero) and the novela cortesana (love-themed literature of escape). The tale of the poisoning of the Bishop of Chiapa with a cup of hot chocolate and the narrow escape of Gage from meeting the same fate at the hands of the besotted murderess is an example of the cloak and dagger style. ${ }^{91}$ The story of the mysterious and opulent nun, Dona Juana, of Guatemala City, who granted private confessions and may have broken her vows of chastity, is an example of the novela cortesana. ${ }^{92}$ Tejera argues that Gage's The English-American represents a strange blend of bombastic English sermons and these more playful Spanish literatures: the style as well as the content of his text reveals a conflicted identity. ${ }^{93}$

\section{Gage the propagandist}

Despite his efforts in The English-American, Gage was aware that his reputation in England was still poor, as neither his old friends, the Catholics, nor his new paymasters, the Puritan hierarchy, were willing to trust him. In 1654, Gage published a pamphlet summarising three sermons that he preached at Deal, depicting himself in the Puritan way as "preacher of the word." In his epistle to his parishioners and "approved friends", he pleaded with them to avoid schisms and seek unity. However, the pamphlet emerged out of a live public disputation he had had with an Independent, and his claim to personal victory reveals his combative nature. He saw his work as defending the Church of England against attacks from the Papists and from those who accused parish churches of being "Babylonish.” The irony of a former Catholic defending the reputation of the Church of England against accusations of being too "Catholic" was not lost on Gage. He used his knowledge of the "Popish church" to win his argument, claiming that because he knew what Catholics practised, and he knew that 
the Church of England was different, then it could not be "Babylonish.” Gage's pamphlet hinted at the direction that his life was taking by this time; in his epistle dedicatory he praised John Limbery, the Justice of the Peace for Middlesex, and an important man in Cromwell's court, who was also one of the commissioners for the planned expeditions to the West Indies, which would be the last adventure in Gage’s life. ${ }^{94}$

The publication of Gage's The English-American and his crucial authority as an eyewitness positioned him on the "right" side of the political divide as a supporter of Cromwell's regime. In the text he reiterated his faith in a Protestant God who "suffered not the meanest and unworthiest of all his Creatures...to be quite blinded with Romish Errors and Superstitions, which have double blinded the purblind heathenish Idolaters”, and instead "safely guided him back to relate to England the truth of which no other English eye did ever yet behold”. ${ }^{95}$ And when he published his book, The English-American, Gage realised how valuable this truth might be to the Puritan authorities, writing in his epistle dedicatory to Sir Thomas Fairfax that “To your Excellency therefore I offer a New-World”. ${ }^{96}$

In the mid-1650s, Gage's Atlantic credentials, about which he boasted to Fairfax, allowed him to further ingratiate himself with the Puritan government by advising them on the ambitious "Western Design”: Cromwell's plan to use naval and land forces to capture the island of Hispaniola from the Spanish. The idea of challenging Spanish power in the New World was not new. Since the reign of Elizabeth I, through the use of the propaganda of the Black Legend, writers had encouraged English involvement in trading and colonising in the region. Colonial theorists such as Walter Raleigh, Richard Hakluyt and Francis Bacon promoted English involvement in the Caribbean for the good of the English and to reduce the power of the Catholic Spanish. Under Cromwell a projected war against the Spanish was very popular and had been promoted in Parliament since 1620, but Cromwell did not want a European engagement. ${ }^{97}$ Supported by Thomas Modyford, later Governor of Jamaica, Gage’s 
testimony that Spanish holdings in the Americas would be easy to capture because of the support the English would receive from the Natives and from African slaves, was crucial and erroneous. Cromwell wanted to cut off the routes of the treasure ships, thus bankrupting Spain, and then take over the Spanish empire. ${ }^{98}$

The mission failed because of ill-disciplined soldiers and sailors (many of whom had been press-ganged), disagreements between the generals, and Gage's misleading advice about the ease of invasion. S.A.G. Taylor insists that the failure was entirely Gage's fault, but in reality the expedition was mismanaged from the start. ${ }^{99}$ Gage's account presented to Cromwell and his Council survives in the Thurloe papers, and while it was overly optimistic with the tone of a promotional tract, it cannot be deemed wilfully inaccurate. Gage had little personal experience of Hispaniola and was, in effect, telling his paymasters what he believed they wanted to hear. He was also overjoyed to offer his expertise in an area of his life with better memories, no longer solely being required to inform against prominent Catholics in domestic trials. Even in this document Gage reiterated his loyalty, showing again that he felt always under suspicion. He said that he was not acting with a "jesuiticall spirit" trying to remove soldiers from England so that the country may be undefended. ${ }^{100}$ Gage underestimated the resistance shown by Spaniards and Natives and the predicted support from the slaves of the island never materialised. The error of recommending an attack on Hispaniola may be interpreted as Gage's because he did say that it would be symbolically impressive to take that first Spanish plantation. However he actually presented Hispaniola as only one of many avenues of attack for the English. His preferred method was landing a fleet at Honduras and from there moving into Guatemala. ${ }^{101}$ Thomas Modyford also did not conclude that Hispaniola should be the target. He too preferred an attack on the New Spanish mainland rather than the islands, suggesting an attack to the south via Trinidad and then up the Orinoco river to Carracas and Cartagena. He emphasised that the financial return from the 
islands would be small and that large settlements would be needed to hold them, whereas on the mainland the Spanish could be cut off from their wealth and the resources available to the English, including the labour of the Natives and "gold and silver and pearl besides hides and tallow.” ${ }^{102}$ Prior to sailing with the Western Design fleet as a chaplain, Gage issued a new edition of The English-American on Cromwell's instruction, ostensibly to demonstrate a better grasp of the English language. But with very few changes of syntax and vocabulary, instead the book served as a promotional tract for Cromwell's plans in the New World.

The mission's strategic failures were compounded by poor diet and high rates of diseases, such as malaria, dysentery and yellow fever. By the end of 1655 around 280 Englishmen were dying every week in Jamaica. ${ }^{103}$ Failing to acquire Hispaniola, as a consolation prize the forces captured Jamaica, and Gage, who travelled to the Caribbean as one of the twenty chaplains in Admiral Penn's Western Design fleet, was present at the negotiations with the Spanish Governor. Gage told the Spanish governor that just as the Spaniards had taken Jamaica from the Indians, the English would now take it from them. ${ }^{104}$ Cromwell was disappointed with Jamaica as it had no gold or silver mines and was not well situated to trap the plate ships on their way to Spain but he was determined to hang on to it. ${ }^{105}$

In the 1650s, a letter was sent from the president of Douai College to the Pope's nephew, Cardinal Barberini, saying that Gage "has returned to a better state of life." ${ }^{106}$ Is it possible that Gage intended to return to the bosom of Rome? Gage's voyage to Jamaica alone, without his wife, has been interpreted as a sign that he had repented his apostasy, but this is wishful thinking on the part of Godfrey Anstruther, a pro-Catholic author, as the leaders of the Western Design would not have tolerated a closet Catholic in charge of the men's spiritual welfare on board their vessels. ${ }^{107}$ The challenging conditions negotiated by Catholics within the English Atlantic World were considerable and changed as political expediency dictated colonial policy. Scott Spurlock places Catholics in a "liminal but 
integral” position on the English colonial frontier. ${ }^{108}$ Later in the century Irish Catholic free and forced labourers carved out a life for themselves in the Caribbean on the margins of English colonial society as shown by Jenny Shaw's account of Irish Catholics who were perceived in racialised ways by the English authorities as simultaneously "white and not white.” ${ }^{109}$ It seems unlikely that Gage’s hubris extended to envisioning his future as a closet or openly-practising Catholic in the new contested, vulnerable English territory in the Caribbean. Surely it is more likely that he intended to continue self-identifying as a loyal Protestant, whether a performance or not. The point is moot because the taking of Jamaica was fatal to Gage who, along with many others, lost his life in 1656 on the yellow fever- and dysentery-ridden island, at that time referred to as "Golgotha." His burial place is unknown, probably an unmarked mass grave. Gage left no will but his widow and children were awarded a small pension by the English government in return for his services.

\section{Conclusion}

To many scholars Thomas Gage provides a footnote in history. Among those interested in the Atlantic World, Gage is remembered as one of the first Englishmen to observe firsthand, life in the interior of Spanish America, but for most, his legacy is as a loathsome apostate willing to betray his friends and family in return for his own security. This article will not rehabilitate Gage's reputation, but has engaged with the complexities of Gage's public and private personae. Gage’s significance is in his ability to cross confessional and national boundaries, a truly transnational figure who, in consciously moving between identities, behaved Atlantically throughout much of his life. By looking closely at the relationships between author, printer and patron, and by examining the context of his conversion we can access a more subtle Gage. Gage’s words demand a subtle interpretation, acknowledging that the meaning of his work changed depending on the time in which it was published. Finally, Gage 
conformed to the needs of the state and the Church of England choosing pragmatism over religious or familial loyalty.

Gage lived through a time of significant epistemological shift and religious turmoil. The theoretical position of religion was changing at the very time when Europeans in huge numbers were willing to sacrifice their lives in the name of religious truth. Scriptural authority was increasingly tested as scholasticism was rejected and the authority of nature came to the fore. In England subscribing to Catholicism was not only seen as religious error but the entire "truth" of doctrine was challenged and unintentionally undermined by writers such as Thomas Hobbes. And yet this development took place alongside a radical politicisation of religion in England, as national and political identity became bound up with doctrinal and theological choices. Through the accident of his birth as a Catholic, to his youthful adventure on the other side of the world, to his ignominious return and conversion and collusion with the state, Gage was buffeted by these trends and chose from limited options in order to avoid being tried himself for his religious beliefs.

\section{Notes}

${ }^{1}$ The "White Atlantic" is becoming a subject for study in its own right rather than being the default normalized “Atlantic”, see Armitage, “The Red Atlantic,” 479.

${ }^{2}$ For example, the seminal work by Armitage and Braddick, eds., The British Atlantic World, but also see Hornsby, British Atlantic, American Frontier and Mancke amd Shammas, eds., British Atlantic World.

${ }^{3}$ Elliott, Empires.

${ }^{4}$ Campos, "English Encounter with Chocolate"; Anstruther, A Hundred Homeless Years; Newton, Gage in Spanish America. 
${ }^{5}$ Steinman, Account of the Manor, 21.

${ }^{6}$ Clifton, “Fear of English Catholics,” 24, 35.

${ }^{7}$ Hauran, Catholics in Caroline England, vii. This view is confirmed by Michael Questier, although he argues that the Oath of Allegiance of 1606 did represent a robust state response to the Gunpowder Plot. See Questier, “Loyalty, religion,” 311-329.

${ }^{8}$ Middlesex Session Rolls, Gaol Delivery Roll. London Metropolitan Archives, MJ/SR/1068.

${ }^{9}$ Ibid., p. 37. See also Lake, “Anti-Popery”.

${ }^{10}$ Oldridge, Strange Histories, 152.

${ }^{11}$ Marotti, Religious Identity, 11.

12 Tejera, “Spanish-English Relationship,”

http://www.sederi.org/docs/yearbooks/06/6_22_tejera.pdf.

${ }^{13}$ Steinman, Account of the Manor, 52.

${ }^{14}$ Newton, Gage in Spanish America, 35.

${ }^{15}$ Acts of the Privy Council August 1616-December 1617, 264, 299.

${ }^{16}$ For example Gage, The English-American, 24.

${ }^{17}$ Ibid, 199.

${ }^{18}$ Ibid., 202.

${ }^{19}$ Ibid, 204.

${ }^{20}$ Ibid., 204.

${ }^{21}$ Newton, Thomas Gage, 180.

${ }^{22}$ Anstruther, A Hundred Homeless Years, 166-68.

${ }^{23}$ Foley, Records of the English Province; Anstruther, A Hundred Homeless Years.

${ }^{24}$ Corby, Certamen Triplex; Leedes, Petri Writi Sacerdotis Angli, 29; Foley, Records, vol. 1, 510. 
${ }^{25}$ Foley, Records, vol. 2, 524, 528.

${ }^{26}$ Thompson, Thomas Gage’s Travels, xv.

${ }^{27}$ Newton, Gage in Spanish America, 9.

${ }^{28}$ Caldwell, The Puritan Conversion Narrative, 46. See also Questier, Conversion, Politics and Religion.

${ }^{29}$ Gage, English-American, 199.

${ }^{30}$ Ibid., 197.

${ }^{31}$ Ibid., 210.

${ }^{32}$ Ibid, 198.

${ }^{33}$ In 1628, the still Catholic Gage was exposed in a similar way when he was mentioned in another conversion narrative by Lewis Owen entitled The Unmasking of All Popish Monks, Friars and Jesuits. Gage's time training in Spain was characterised as one of luxury, sin and excess by Owen as he wrote that Gage was 'a gentleman well descended but a roaring boy, fit to keep company with any English collapsed lady’. Anstruther, A Hundred Homeless Years, 160. James Wadsworth and Thomas Gage also shared an interest in chocolate. Wadsworth translated the tract A Curious Treatise on the Nature and Quality of Chocolate written in Spanish by Antonio Colmonero doctor in physicke and chirurgery.

${ }^{34}$ Fuchs, “An English Picaro,” 63.

${ }^{35}$ Gage, English-American, 211.

${ }^{36}$ Hauran, Catholics in Caroline England, 131-132. Gage said that 'I chanced to be discovered' by John Gray and acknowledged his brother's influence in protecting him, although he claimed that this protection was not welcome as he intended to convert, Gage, English-American, 206. 
${ }^{37}$ Fulbrook, Anatomy of a Dictatorship, 50. A useful historical comparison to illuminate the motives of Gage is with the ordinary Germans who gave evidence to the Stasi and Gestapo during the mid-twentieth century. Denunciations to the Gestapo often resulted in the execution of the victim. Many reasons drove an individual to give evidence against their neighbours. The informer's response to authority was crucial and they were motivated by fear, obedience and duty and by belief in ideology. However, also important was an individual's sense of self and their relationship to the community around them. Many informed to achieve a feeling of importance or out of jealousy or because of neighbourhood feuds, as informers tried to remove economic competitors and troublesome neighbours as well as more traditional ‘undesirables’ such as Jews and communists.

38 Thompson, Thomas Gage’s Travels, xxxvii-xxxviii.

${ }^{39}$ Gage, A Duell, 6.

${ }^{40}$ Foley, Records, vol. 1, 563.

${ }^{41}$ Rosengarten, Thomas Gage, 27.

42 See also Sebens, “Thomas Gage,” http://historicaltextarchive.com/sections.php?action=read\&artid=451.

${ }^{43}$ Cressy and Ferrell, Religion and Society, 2.

${ }^{44}$ Calendar of State Papers Domestic: Interregnum, http://www.british-history.ac.uk/

${ }^{45}$ Gage, A Duell, 8.

46 Foley, Records, vol. 1, p. 141; Calendar of State Papers Domestic: Interregnum, http://www.british-history.ac.uk/

${ }^{47}$ Sebens, Thomas Gage.

${ }^{48}$ Fitzmaurice, Humanism and America; Armitage, Ideological Origins.

${ }^{49}$ Gentles, “Thomas Fairfax,” http://www.oxforddnb.com/view/article/9092?docPos=2 
${ }^{50}$ Scott, “Thomas Chaloner,” http://www.oxforddnb.com/view/article/5042?docPos=3

${ }^{51}$ Newton, Thomas Gage, xxvi.

${ }^{52}$ Armitage, Ideological Origins, 195. During the seventeenth century, The English-American went through four English editions that appeared in 1648, 1655, 1677 and 1699, and were produced by two associated printing families, the Cotes and the Clarks. Richard Cotes, whose printing business was based at the Barbican on Aldersgate Street, printed the 1648 edition only four years before his death. He was brother and successor to Thomas Cotes who was part of a printing syndicate that had produced Shakespeare's second folio. Richard was married to Ellen Cotes, and she succeeded him in the business and in 1655 printed the second edition of Gage's text released to support the Western Design. Ellen's business was a substantial one; she had three presses, two apprentices and nine pressmen in 1666. All three Cotes were printers to the parish clerk for St. Giles without Cripplegate in London, producing Bills of Mortality for the parish. Ellen Cotes worked with Andrew Clark on a number of books such as The History of the Duke of Espernon, and Andrew was the printer of the third edition of Gage’s book in 1677. Andrew's widow Mary took over the business on his death and printed the fourth edition of Gage's book in 1699. Clark's business was also on Aldersgate Street in close proximity to the Cotes's. This shows how the printing of particular books could remain in the hands of one business for years at a time. During this period booksellers frequently acted as publishers for a particular text, sometimes indicated by 'printed for' appearing on the colophon. This only appears once in the first four editions of Gage’s work: the 1699 edition was printed by M. Clark for J. Nicholson and T. Newborough. Thomas Newborough was described by Plomer as being 'one of the leading men in the book trade and concerned with many of the most important publications of the time'. He was also described as a 'good churchman': significant considering how the text of The English- 
American was manipulated after the Restoration to give a different message. The other bookseller-publisher of the 1699 edition was John Nicholson who worked in partnership with Newborough on a number of other texts including a Latin Testament. John Dunton, Nicholson's contemporary, said of him that his talent was for 'projection': selecting books that would be successful, although his selection of travel narratives 'will be a little posthumous'. That phrase seems to mean that knowledge of Nicholson's correct selection of travel narratives, including that of Gage, would remain hidden until after his death. The booksellers named on the colophons of earlier editions were just that: shop or stall owners engaged in the selling of books, as evidenced by the words 'sold by' on the colophons. One of the booksellers of the first edition was Humphrey Blundon, a key civil war publisher who was part of Samuel Hartlib's circle. Two of the sellers of the 1677 edition are also noteworthy: John Martyn who also acted as publisher for the Royal Society and Walter Kettilby who was a copyright owning bookseller who specialised in divinity books.

${ }^{53}$ Canny, “Protestant or Catholic?”

${ }^{54}$ Gage, English-American, 76.

${ }^{55}$ Ibid, 79.

${ }^{56}$ Swingen, Competing Visions of Empire, 57, 159.

${ }^{57}$ Newton, Thomas Gage, p. xi.

${ }^{58}$ There is no evidence as to who produced the woodcut, but it would have been under instruction from the publisher. The other continental early modern editions were published in Paris, 1676, Amsterdam 1682, 1699, 1700, Utrecht 1682. See www.prdl.org

59 Thompson, Thomas Gage's Travels, xxx-xxxiii.

${ }^{60}$ Gage, English-American, sig. A2.

${ }^{61}$ Ibid., 81. 
${ }^{62}$ Ibid., 110.

${ }^{63}$ Crosby, Columbian Exchange.

${ }^{64}$ Laurence, “Gage and Tropical Medicine,” 267.

${ }^{65}$ Gage, English-American, 109.

${ }^{66}$ Campos, “English Encounter with Chocolate,” 183.

${ }^{67}$ Earle, Body of the Conquistador, 47.

${ }^{68}$ Gage, English-American, 22. Stubbe, The Indian Nectar.

${ }^{69}$ Rosengarten, Thomas Gage, 194.

${ }^{70}$ Gage, English-American, 103-109.

${ }^{71}$ Ibid., 80.

${ }^{72}$ Ibid., 15.

${ }^{73}$ Ibid., 1.

${ }^{74}$ Newton, Thomas Gage, 118.

${ }^{75}$ Ibid., 53.

${ }^{76}$ Ibid., 149.

${ }^{77}$ Oldridge, Strange Histories, 15.

${ }^{78}$ Gage, English-American, 8.

${ }^{79}$ Ibid., 168-173.

${ }^{80}$ Ibid., 178.

${ }^{81}$ Ibid., 162, 192.

${ }^{82}$ Newton, Gage in Spanish America, 93.

${ }^{83}$ Newton, Gage in Spanish America, 100; Gage, English-American, 117.

${ }^{84}$ Chaloner, "laudatory poem," in Gage, English-American, sig. A4.

${ }^{85}$ Rosengarten, Thomas Gage, 1. 
${ }^{86}$ Oviedo's Natural History, xvi.

${ }^{87}$ Cortes: The Life, $\mathrm{xvi}$.

${ }^{88}$ Ibid., xxxii.

${ }^{89}$ Acosta’s Natural History, 454.

90 Thompson, Thomas Gage’s Travels, xx.

${ }^{91}$ Gage, English-American, 103-104.

92 Ibid., 122-128.

93 Ibid., 204.

${ }^{94}$ Ibid., sig A2.

${ }^{95}$ Ibid, 82.

${ }^{96}$ Ibid, sig A3.

${ }^{97}$ Capp, Cromwell's Navy, 87.

${ }^{98}$ Ibid., 88.

99 Taylor, The Western Design, 5.

100 “State Papers December 1654,” Papers of John Thurloe, vol. 3, Dec 1654-Aug 1655, 59.

101 Ibid., 60.

102 “A Paper of Colonel Muddiford concerning the West Indies December 1654,” Papers of John Thurloe, 63.

103 Taylor, The Western Design, 90.

${ }^{104}$ Ibid., 56.

105 Ibid., 89.

${ }^{106}$ Anstruther, A Hundred Homeless Years, p. 192.

107 Ibid., 192.

${ }^{107}$ Spurlock, 'Catholics in a Puritan Atlantic', 38. 
107 Shaw, Everyday Life, 2.

\section{Acknowledgements}

This work was supported by a grant of $£ 700$ from the Catholic Records Society.

\section{Disclosure statement}

I have received no financial or other benefit resulting from this research.

\section{Notes on contributor}

Catherine Armstrong is Lecturer in Modern History at Loughborough University. She has published two monographs on representations of landscape in colonial North America: Writing North America in the Seventeenth Century (Ashgate, 2007) and Landscape and Identity in North America's Southern Colonies (Ashgate, 2013). She has also co-authored, with Laura Chmielewski, a textbook on the Atlantic World: The Atlantic Experience: Peoples, Places, Ideas (Bloomsbury, 2013). More recently her work has focused on the boundaries of enslavement and slaves' use of marginal landscape places and she has an article on this published in March 2017 in the journal Slavery and Abolition.

\section{References}

Acts of the Privy Council August 1616-December 1617. London: His Majesty’s Stationery Office, 1927.

Armitage, David. The Ideological Origins of the British Empire. Cambridge: Cambridge University Press, 2000. 
Armitage, David. “The Red Atlantic.” Reviews in American History 29, no. 4 (2001): 479486.

Armitage, David, and Michael J. Braddick, eds. The British Atlantic World 1500-1800, $2^{\text {nd }}$ edition. Basingstoke: Palgrave Macmillan, 2009.

Anstruther, Godfrey. A Hundred Homeless Years: English Dominicans 1558-1658. London: Blackfriars Publications, 1958.

Caldwell, Penelope. The Puritan Conversion Narrative. Cambridge: Cambridge University Press, 1983.

Calendar of State Papers Domestic: Interregnum, accessed via www.british-history.ac.uk.

Campos, E.V. “Thomas Gage and the English Encounter with Chocolate.” Journal of Medieval and Early Modern Studies 39 (2009): 183-200.

Canny, N. “A Protestant or Catholic Atlantic World? Confessional Divisions and the Writing of Natural History.” Proceedings of the British Academy 181, no. 23 (2012): 83-121.

Capp, Bernard. Cromwell's Navy: The Fleet and the English Revolution 1648-1660. Oxford: Oxford University Press, 1992.

Clifton, Robin. “The Popular Fear of English Catholics during the Revolution.” Past and Present 52 (August 1971): 23-55.

Corby, Ambrose. Certamen Triplex. Antwerp, 1645.

Cortes: The Life of the Conqueror by his Secretary Francisco Lopez de Gomara. Translated and edited by Lesley Byrd Simpson. Berkeley: University of California Press, 1965.

Cressy, David and Lori Anne Ferrell, eds. Religion and Society in Early Modern England: A Sourcebook. London: Routledge, 1996.

Crosby, Alfred. The Columbian Exchange: Biological and Cultural Consequences of 1492. Westport: Greenwood Publishing Company, 1972. 
Cust, R., and A. Hughes, eds. Conflict in Early Stuart England: Studies in Religion and Politics 1603-1640. London: Longman, 1989.

D’Mignolo, Walter, ed. Acosta's Natural and Moral History of the Indies. Durham, NC: Duke University Press, 2002.

Earle, Rebecca. The Body of the Conquistadors: Food, Race and the Colonial Experience in Spanish America 1492-1700. Cambridge: Cambridge University Press, 2012.

Elliott, John. Empires of the Atlantic World: Britain and Spain in America 1492-1800. New Haven: Yale University Press, 2006.

Fitzmaurice, Andrew. Humanism and America: An Intellectual History of English Colonisation 1500-1625. Cambridge: Cambridge University Press, 2003.

Foley, Henry. Records of the English Province of the Society of Jesus. London: Burns and Oates, 1877.

Fuchs, Barbara. “An English Picaro in New Spain: Miles Philips and the Framing of National Identity.” The New Centennial Review 2, no. 1 (2002): 55-68.

Gage, Thomas. The English-American. London, 1648.

Gentles, Ian. “Thomas Fairfax.” Oxford Dictionary of National Biography. http://www.oxforddnb.com/view/article/9092?docPos=2

Hauran, Martin. The Catholics in Caroline England. Stanford: Stanford University Press, 1962.

Hornsby, Stephen. British Atlantic, American Frontier. Boston: University Press of New England, 2004.

Laurence, B.R. “Thomas Gage and Tropical Medicine in the New World.” Transactions of the Royal Society of Tropical Medicine and Hygiene 65, no. 2 (1921): 267-268.

Leedes, Edward. Petri Writi Sacerdotis Anglie Society. Jesu. Mors. Antwerp, 1651. 
Mancke, Elizabeth and Carol Shammas, eds. The Creation of the British Atlantic World. Baltimore: Johns Hopkins University Press, 2005.

Marotti, Arthur. Religious Identity and Cultural Fantasy: Catholic and Anti-Catholic Discourses in Early Modern England. Notre Dame: University of Notre Dame Press, 2005.

Middlesex Session Rolls, Gaol Delivery Roll. London Metropolitan Archives, MJ/SR/1068.

Newton, Arthur Percival. Thomas Gage, The English American: A New Survey of the West Indies, 1648. London: George Routledge \& Sons, 1946.

Newton, Norman. Thomas Gage in Spanish America. London: Barnes and Noble, 1969.

Oldridge, Darren. Strange Histories. Abingdon: Routledge, 2006.

Oviedo's Natural History of the West Indies. Translated and edited by Sterling A. Stoudemire. Chapel Hill: University of North Carolina, 1959.

Questier, M., Conversion, Politics and Religion in England 1580-1625. Cambridge: Cambridge University Press, 1996.

Questier, M. “Loyalty, religion and state power in early modern England: English Romanism and the Jacobean Oath of Allegiance.” The Historical Journal 40 (1997): 311-329.

Rosengarten, Frederic Jr. Thomas Gage: The English American Traveller. Princeton: Princeton University Press, 1989.

Scott, David. “Thomas Chaloner," Oxford Dictionary of National Biography. http://www.oxforddnb.com/view/article/5042?docPos=3.

Sebens, Hether. “Thomas Gage.” Historical Text Archive. Accessed 1/8/12. $\underline{\text { http://historicaltextarchive.com/sections.php?action=read\&artid=451 }}$

Shaw, Jenny. Everyday Life in the Early English Caribbean: Irish, Africans and the Construction of Difference. Athens, GA: University of Georgia Press, 2013. 
Spurlock, Scott. “Catholics in a Puritan Atlantic: the Liminality of the Empire's Edge”, in Gribben, C. and Spurlock, S. eds., Puritans and Catholics in the Trans-Atlantic World 1600-1800. London: Palgrave Macmillan, 2015.

Steinman Steinman, G. Some Account of the Manor of Haling in the Parish of Croydon, Surrey, with Notices of the Family of Gage of that Place. London, 1835.

Stubb, Henry. The Indian Nectar or a Discourse Concerning Chocolata. London, 1662.

Swingen, Abigail. Competing Vision of Empire: Labour, Slavery and the Origins of the British Atlantic Empire. New Haven: Yale University Press, 2015.

Taylor, S. A. G. The Western Design: An Account of Cromwell's Expedition to the Caribbean. Kingston, Jamaica: Solstice Productions, 1965.

Tejera, Dionisia. “Spanish-English Relationship in the Work of Thomas Gage.” Spanish and Portuguese Society for Renaissance Studies. Accessed 1/8/12. http://www.sederi.org/docs/yearbooks/06/6_22_tejera.pdf

Thompson, J. Eric S. Thomas Gage's Travels in the New World. Norman: University of Oklahoma Press, 1958. 